\title{
An Analytical Study on The Effective Approaches to Facilitate Higher Education Cooperate with Industry: Based on Faculty Members Perspective
}

\author{
Andik Asmara, Ming-Chang Wu \\ National Yunlin University of Science and Technology, Yunlin, Taiwan, ROC
}

\begin{abstract}
The government in the world through constitution and ministry establish a law to develop and strengthen the economic system; one of the laws regard education and industrialization. The part of education types which is close with industries are vocational schools and universities. Each university is encouraged to enhance collaboration with industry through a lot of effort. However, the crucial component to actuate collaboration in education viewpoint is the provision of the proponent facilities. Qualitative research was conducted through interviews to collect the data, and grounded theory was used to analyze the data. The six months internship, research collaboration on-job training establishes facilitators i.e. a person who facilitates cooperation effectively.
\end{abstract}

Keywords - University Industry Cooperation, Facilitate, Faculty members perspective.

\section{Introduction}

Engagement industry into education system is important, in terms of competency and skill improvement needs, facility and technology, and places to internships.

DOI: 10.18421/TEM94-53

https://doi.org/10.18421/TEM94-53

Corresponding author: Andik Asmara,

National Yunlin University of Science and Technology,

Taiwan, ROC.

Email: d10743015@yuntceh.edu.tw

Received: 11 September 2020.

Revised: 02 November 2020.

Accepted: 07 November 2020.

Published: 27 November 2020.

(c))BY-NC-ND 2020 Andik Asmara \& Ming-Chang Wu; published by UIKTEN. This work is licensed under the Creative Commons Attribution-NonCommercial-NoDerivs 4.0 License.

The article is published with Open Access at www.temjournal.com
In [1] describes the involvement of user associations as representatives of enterprises in vocational education to develop skills and competencies that are needed in real practice. The real work world insight needed to give real experience and real condition settings. The real experience can be reached from real workplaces, such as industries and government. Both of them should be open border to engage education to be fusion in real activities.

The phenomena in recent years in industry sectors include the increasing globalization and international competitiveness, in both of private and public sector, then science organization had increased innovationdevelopment activities [2]. In [3] describe that many industries increase in order to open innovation from a source outside the corporation's borders. It has meant that the present year industries have opened an engagement innovation from outside the enterprise. Based on these phenomena, personal or association and organizations may embroil the partnership with industries.

The cooperation base by design is to obtain the benefits of each party. For instance, as in Europe, the successful cooperation relies on alignment with both university and industry strategies. Besides, university and industry have to be able to leverage resources across the university to meet the company's needs [3]. The superior industrial and academic performance can be achieved through collaborations between universities and industries [4].

In other overview, university represents as higher education level, and industry within cooperation has purpose to improve and to update knowledge of faculty members, researcher quality, and to enhance student competency. The cooperation should be constructed on mutualisms, it means for the researcher and students to receive knowledge from the industry, and implement real technologies. On the other hand, the industry obtained high-competent employees from the universities who collaborate. 
However, faculty members' involvement is limited in some parts, even their role is extremely important. For instance, research outcome in the university is just report, article in Scopus paper or patent oriented. In the universities, the faculty members' performance is still mainly measured by teaching hours, academic activities, and publications [5]. Whereas, internship programs are commonly for students and internship is just substitute load of study. One of a mission for each university is to improve faculty members' capabilities, such as lecturers, staff, and students depend on facilitating faculty or university to enhance them. Indeed internship provides an opportunity to enterprise employer and faculty members to work together in defining students' activities, desired learning outcome and expected competency [6]. Therefore, facilitating cooperation between higher education and industry need to identify what had been given to the faculty member, especially in a public higher education.

This study is conducted with collecting data from viewpoints of faculty members in higher education, and was conducted to identify the effective approaches facilitating the cooperation between higher education (focus on university) and industry. The result in this study is highly concerned with practical issues, such as (1) faculty members' (their) intention to take an internship in industries, (2) the potential approach to work together with industries for reciprocal enhancement, (3) the possibility to join research on realistic issues in realistic work environments, and (4) teaching activity programs in both university and industries. These four major issues raise to lead on future implementation approaches to enhance cooperation.

In order to achieve the purpose, the questions that propose in this research could be described as follows:

1. Will the faculty members undertake the internship in industries? Such as in 6 months or in 6 years.

2. Will the faculty members take practical research cooperating with industries? And how to transfer their academic research into or join with practical research in industries?

3. Will students' internship in industries are undertaking for on-job coaching? And how to proceed after coming back to university?

\section{Literature Review}

\subsection{The Study Background Situation in Indonesia Setting}

In 2016, through Instruction of President, Indonesia had a program to revitalize higher education, especially vocational education. Revitalization of higher education had been done through activities such as review of the curriculumbased on-demand market, reorganized studies field or department, the framing of learning education, and fulfillment of lecturer needs. On the other side, the government expanding new post-secondary vocational school which major focus on-demand market for industries.

However, the reality of industry engagement to education is still being improved. For instance, in [7], [8] describe that to stimulate entanglement between university and industry, government issued regulation law No. 35 Year 2007 on tax incentives for business enterprises that support Research and Development (R\&D) activities. The institutional research had been done by [9] and strengthen the argumentation by [8] that had resulted in differences between university and industry in Indonesia due to their structural identities, despite the reality that they share innovation activity. Moreover, as well as result interaction between universities and industries is problematic due to a lack of mutual understanding and an absence of policies to support the universityindustry linkage.

The university is a higher education system in which faculty members need to be more practical in knowledge, skills, and competency. The purpose is to develop students' capability to face future careers. For instance, the internship program has emerged as a bridge between education and work environments that address the gaps in knowledge, skills and/or competencies [6]. Moreover, faculty members as a component in the university are not only academic activity; however, they have a responsibility to do research activity. In [10] describe that the development function of the university is going beyond pure research and teaching activity. Meanwhile the university in a developing country has a function as "antennae" for technological and vocational transformation created in a leading innovation system [10].

\subsection{The University-Industry Cooperation Roles}

The collaboration between university and industries had begun a long time ago. [11] describe that university have collaborated with industry for a long term are more likely to collaborate in the future. Experience with spin-off firms are likewise positively related to collaboration [12] and, correspondingly, older TTOs tend to be more efficient than younger ones [13]. When it comes to enterprise, experience matters as well, for example already having collaborative agreements with other actors tend to stimulate further collaboration among enterprise [14]. Previous experience was such a beyond predictor, that even previous collaboration deemed unsuccessful by enterprise was shown to be positively correlated with the probability of interacting with universities more often [15]. 
The collaboration not only becomes a symbol to each other, but also have a status to make cooperation ready to support the government program. The positive effect in collaboration between university and industry had been shown in previous study [16]. In [17] explain that the collaboration between university and industry that involves and benefits has three main participants; the first is school or universities, in which education systems are to be strengthened. The second is the industry as an important part of human resources development, and the third is the student who is placed to learn practical application and gain experience.

Based on the prior studies, the benefit received from cooperation can be explain as follows. For faculty members and/or university, it can be explained that the collaboration might reinforce traditional characteristics of academic in the situational environment by increasing of publication and patenting rates [16]. In other hand, industries has Research and Development (R\&D) efficiency improved, new market opportunities, and helped them to overcome technological barriers [16]. Certainly, for students with regard to establishing of cooperation, it becomes new place to internship and knowledge update with real technologies.

\subsection{The contribution faculty member to University- Industry Cooperation}

As faculty members in university, they supposed to support the vision and mission of the university. Transforming a mission in the faculty members' activity has become the program and engagement of faculty members. The faculty member can contribute in university and industries cooperation. For instance, the contribution of a faculty member is supporting an internship program, research collaboration, and encourage the student to engage in training in industries.

Internship is to leave the environment of the school and learn advance knowledge, skill and professional service practices from the real organization in an industries [17]. The practice of the internship program for students in improving the experience of the industry includes students who leave school for one to two semesters for their future career. The internship can provide student the experience that cannot be otherwise acquired in university [18]. Previous studies described the five major benefits of internship such as; applying the knowledge's and skills in the classroom to the real or working place; enhancing the industrial knowledge; reducing the unfamiliarity in the workplace; clarifying their ambitions and interests; and faster adaptation that students are convinced they will acquire from the internship [19].

The internship will also be able to enhance the knowledge and skill of the lecturer or staff in faculty. Especially in Indonesia education, the teachers and lecturers who are working in vocational education have to improve and to enhance their knowledge and skill towards the new industrial technologies. In other responsibilities, academic activities such as teaching, research, social community and administration includes knowledge and skill improvement through an internship in industry. The internship can be done in six months to get the optimum benefits we are received.

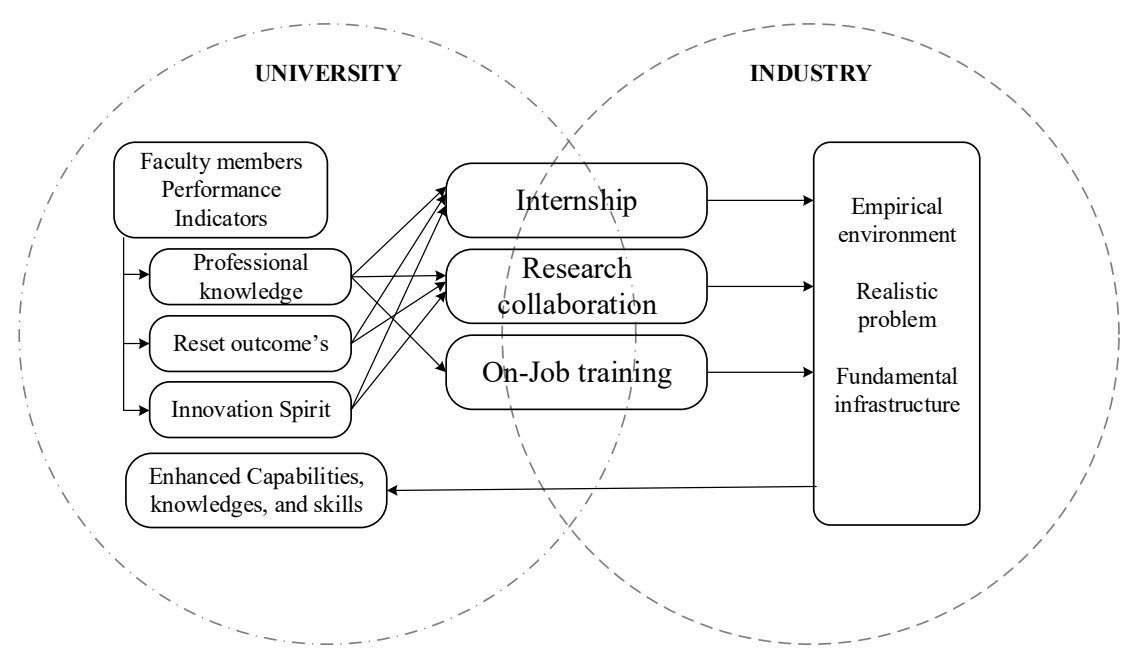

Figure 1. University-Industry Cooperation Framework (adopted and developed from [20]

The other potential benefit in cooperation comes from research collaboration activities. [21] describes that scientific knowledge by public researchers offers new opportunities to promote enterprise innovation effort, which in combination with knowledge that enterprise already has, creates new opportunities for new technology and produce development. Towards a higher possibility that they would establish 
partnership is the universities and enterprise, by which one can recognize that they are dependent on each other knowledge resources [21]. In other overview, enterprise often look for partnership other than universities in pursuing technological initiative due to the mismatch of research interest between universities and industries [21], [22].

One of the most prevalent predictors of collaboration which has been found in the material is that of prior experience in collaboration. This is identified as a prominent factor among researchers, on the university level as well as in enterprise. Among researchers, it was found that previous study in collaboration has a positive influence on further contract research, consulting and collaborative research [23]. Actually, the prior collaborative experience among researchers and enterprise is positively related to the potential and success of the collaboration.

Each collaboration involved industries that should be measured by using several indicators. One of the indicators can be used for the outcome from research activity. For instance, the output of universities are measured as patent, enterprise spin-offs, licenses to industry and/or indicator of employment change or economic growth [21], [24]. Furthermore, [21] explained that industrial Research and Development manager attaches very little importance to measurable performance-metrics such as licenses and patent.

\subsection{Preliminary Conclusion}

The university has roles in the long-term economic growth in three ways, that provides an excellent human resource through education; conducts basic research; and as a source of knowledge for innovative enterprise. The universities and industries work together on cooperation, thus influencing and encouraging the economic growth in countries. The importance of cooperation between university and industry can be seen on prior cooperation experiences, for instance: The policy establishes as a major factor contributing high research and innovation performance in Malaysia [25]; this collaboration in Japan becomes essential vehicles for commercialization university invention by new enterprise [26]. The prior collaboration delivered to the countries becomes advanced industries and economic better growth.

The collaborations with universities mean the relationship between faculty members and individual industry researchers, and also they are focused on specific research-development needs which identifies the individual who is involved [3]. Although collaborations were the relationship between institutions and enterprise, interactions happened between faculty members and the employee and/or employers. Therefore, the faculty members have an important role in the collaboration between universities and industries. The faculty's members are the main factors that can collaborate with industries. They consist of professional knowledge, research outcome, and innovation spirits.

The faculties are part of the university supposed to encourage others to collaborate with industries. Therefore, faculty should be the facilitator of engagement between faculty members and enterprises. The faculty members need support from faculty or university to involve inside the programs. Faculty could offer several programs to obtain interest from industries. They can use the program that has a benefit to each party, such as internships for faculty members, research collaboration, and onjob training engage industries. Three programs of this should be prepared and cooperate sustainably to get the benefit in the long term.

\section{Methodology}

\subsection{Rational of Method}

In order to answer research questions we used five steps shown in Figure2. To facilitate cooperation between higher education and industry based on faculty members perspectives descriptive data are used. The data came from faculty members experiences and foresight. In order to dig up the valuable data, interview was used to collect data from faculty members. The reason we used this method approach are supposed to respond in relevant, accessible, and usable form to fulfill the study purpose.

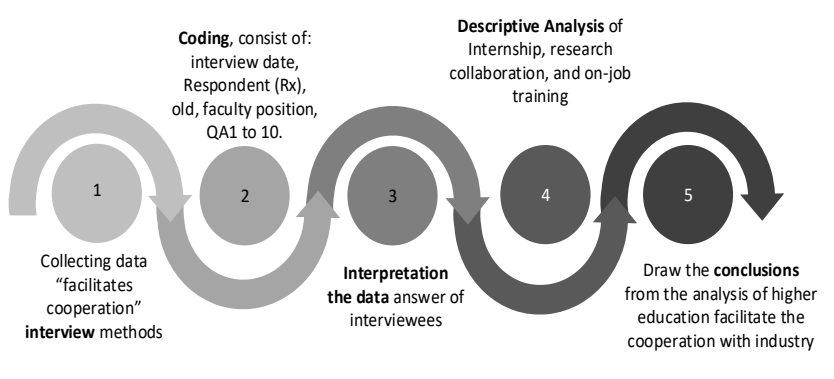

Figure 2. Research procedures

\subsection{Population and Samples}

The faculty members represent population on this study, and took respondents as samples which came from one of best universities in Indonesia setting. The respondents consist of six faculty members with details that are (initial-years old-position): R1-56dean; R2-51-Intership coordinator; R3-48-distinguish researcher; R4-40-vice dean academic affair; R5-37internship coordinator of electrical engineering; and 
R6-32-internship coordinator of mechanical engineering. All participants had willingness to share their experience and insight.

\subsection{Data Collection}

The interview method was used to collect the data from six respondents. The conducted interview spent a long time between 10 minutes -20 minutes. The interviews was recorded by digital recorder into .WAV files. Ten questions were created and given to respondents to dig up their experiences and insightfully.

\subsection{Data Analysis}

The grounded theory approach was used to data analysis in this study. This method consists of five steps (Figure-3) to address final conclude from data respondents' answers in one conclusion, that is called saturation.

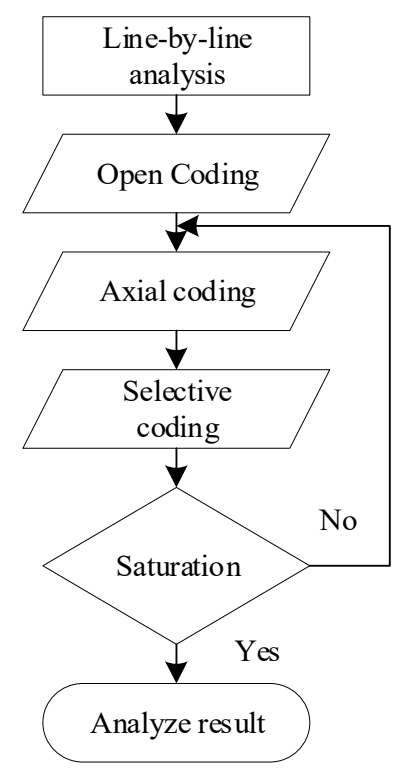

Figure 3. Grounded Theory technique (adopted from [27])

\section{Finding and Discussion}

The scope of a university includes faculty members, education, research, community services, and research outcome. On the other side, the scope of inside industry includes top management, employees, technology, innovation/research and development, and products. The whole components are important; however, in this study the focus is on components engaged to facilitate cooperation with industry. Based on literature on previous topics there are three components which have to do with engagement in a cooperation program between the university and industry. In addition, the components can be a way to improve and enhance the capability of faculty members. Those components are the internship for the faculty members, a research collaboration between university researcher and industry, and onjob training in order to implement and improve competency skills in the real work environment.

In Figure4 we show a meaning of faculty and/or university facilitating to cooperate between university and industry. Three major issues to improve cooperation include internship as long 6months, research collaboration, and on-job training in the industry. The prefix in this finding and discussion has a brief explanation as follows; (1) internship for the faculty members as long 6-moths need policies from faculty or university related to working leave and academic task. Activity in the internship does not disturb academic tasks as a teacher, lecturer, or staff. Furthermore, innovations become triggering to make a commitment together about internship and need a man as a facilitator to be a communicator to industries. (2) To conduct research, engage industries in the collaboration needs a new idea (innovation), i.e. what to implement in industries. In addition, the achievement of the research outcome consists of journals, patents, and product/idea that can be implement or commercial. Furthermore, equal to the previous issues we need a man as a facilitator to be a communicator to industries. (3) On-job training engages industries, whose curriculum in faculty needs to link and match with the industry need. In addition, we also need a man as a facilitator to be a communicator to industries.

\subsection{Internship Program}

In this case, the internship is the position of a faculty member (lecturer or staff) who works in an organization or enterprise, sometimes without pay, in order to obtain work experience or satisfy a requirement for qualification. The internship gives someone real experience who has never taken internship in industry. The experience such as implementing knowledge, skill, and technologies in the real environment of work are obtained. The mean of the internship is activity outside of school in order to learn advanced knowledge, skill and professional service practices from the real experience [17].

Implementation internship in several universities has boundaries, especially university whose position is far from the industrial area. Internship is just a program for the student to completism curriculum or credit semesters in the faculty. The idealism faculty members such as lecturer and staff should take internship in the industry. This study focuses on how to facilitate UIC using internship program for the faculty members. 
Argument-1: Understand real technology and realistic effect in teaching method

The goal of the collaboration from the internship program is to understand the real technologies and get a realistic effect. The activities of collaboration have become important in developing advanced technologies and enhancing academic progress [4]. To apply knowledge into the application or realworld one is supposed to use relevant the industries [25]. Industries are places to implement their knowledge and skills base on theory and academic literatures.

The raw data of respondent argument has the majority answer from the all respondents that have similarity. The point answer is described as follow:
"Internship program is great for the faculty member because we gained real experience in the real work environment. Furthermore, lecturer or staff finished internship program, return into the education environment can implement in the teaching methods."

The faculty's member as a respondent has a thought that internship is great program to advance competencies and balance with work skill needed in industries. They can use the knowledge and skill that achieved in academic to implement on industry. Moreover, a participant in the internship program received knowledge related to new technology that is used in industries. This is a prominent point to lead in academic or education classical. In addition, influencing colleagues can be done through sharing information or group discussions.

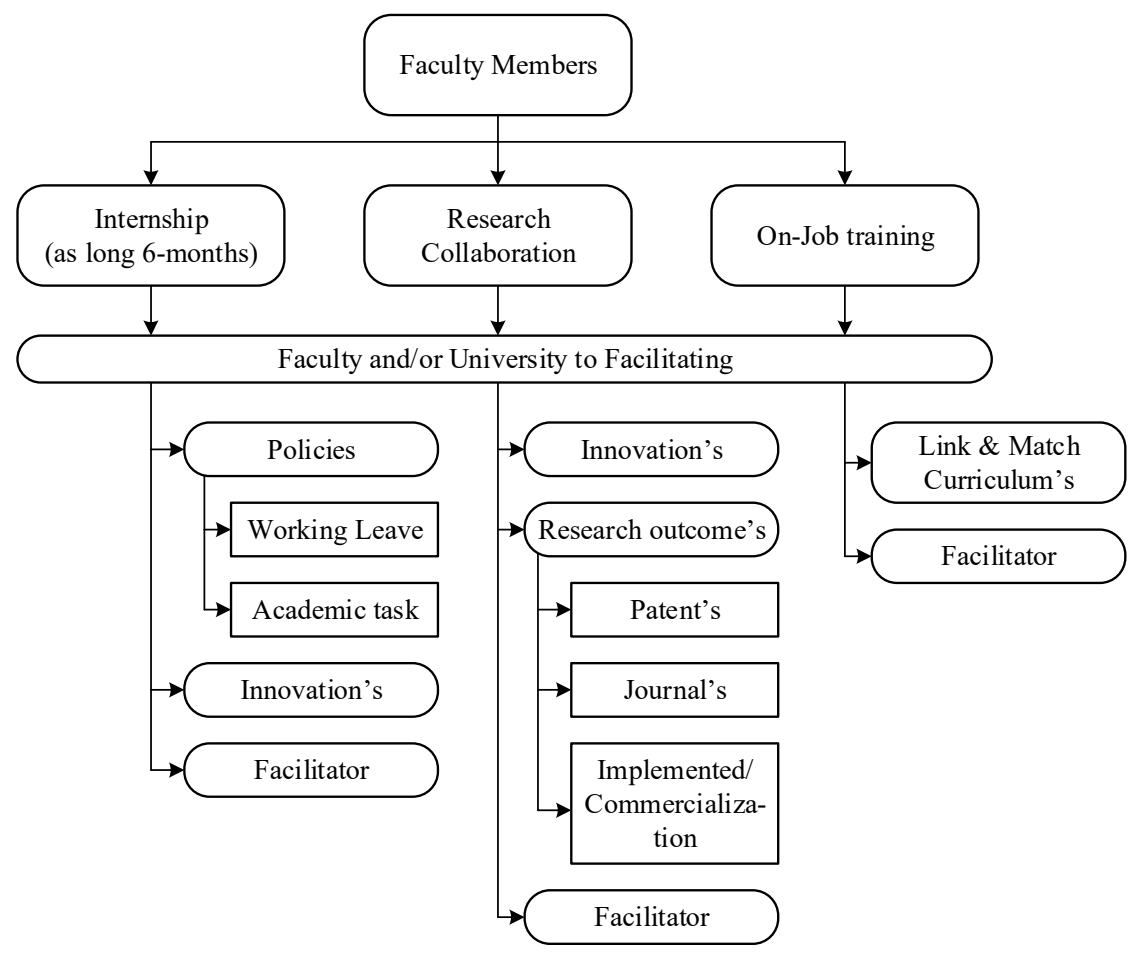

Figure 4. Finding facilitate cooperation between university and industry

Argument-2: Long times internship and implement six months internship

The injunction of long-time internship program depends on faculty or university to faculty members. Long time to internship has impact to experience they get from industries. One opinion of chief medical technologies has described that internship can spend six-months attending continuous professional education programs, so they can be updated in practice of the profession as well [28]. The kind of job with regard to profession title have 6 months requirement for minimum internship. Since being a teacher and a lecturer are professional jobs, there is a necessity for knowledge's update. Therefore, the time of internship program will be implemented to the faculty members in six-month period.
The raw data of respondent argument has the majority answer around 2 months up to 3 months; however, this is a minimum time requirement from industries. The participant on this condition received minimum information from industry, such as introduction about machine, organization, and process system. A short-time internship causes participant learns fewer problems or cases in the work environment of industry.

Basis on literature, internship is to be optimal through six-month program in industry. What happens if this policy is implemented in the faculty to all faculty members? Furthermore, there is a unique answer from the respondent majority as follows: 
"If this policy implement now is impossible, because faculty member has responsibility for teaching activity and another activity else. This becomes a great program when faculty or university establish new policy related six months in the industry and override academic activity in faculty and university."

The problem to implement a six-month internship in the industry comes from faculty member's responsibility being a lecturer or staff. Moreover, as a faculty member in the national university (civil servant) he or she should not have their work left. Furthermore, we need several internal policies equal to the faculty or the university level. These policies make the participant to internship programs in industries feel comfort, because they leave from academic responsibility and then focus on how to implement knowledge and solve the industrial problems.

\section{Argument-3: Improving cooperation with industries}

The cooperation with industries has to have the matching of intent each party and the goal has a benefit to both. In [29] was explained that the potentially successful of collaboration means matching the level of precondition between university and industry. In addition, collaboration has the meaning of working together to develop a solution to problems, thereby create insights for theory, and practice [4]. In other words, collaboration is allowing new idea to be put into practice in such a way that they are viable for commercialization and useful to end user. The previous literature has shown the collaboration construct with matching intent to solve the problem using new ideas and innovation. The key point is innovation in cooperation activities.

From the respondent data, the majority of respondent ensures with an internship that improve cooperation between university and industry. Furthermore, innovation becomes a major key to begin cooperation between university and industry. These answer data were more specific on how to ensure cooperation both as follow:

"Depend, you have the innovation to share and implement in industry or not? If you have an innovation, the industry is welcome to you for an internship and further action is conduct cooperation." (respondent 4)

The raw data above has meant the succession actor in the cooperation is one of the people in the faculty. The person who has the innovation that can be implemented in industries become triggers to industries engaged in cooperation. Therefore, the collaboration between university-industry by designing and implementing of innovation, in addition the innovation is to be the focal aim of UIC [29].
Internships for faculty members have benefits for each party, however how do begin cooperation with industries need a person that has an innovation. The person among faculty members who has a lot of experience and innovation will constantly be sought by industries to work together in cooperation. On another hand, Industries highly expect that university and faculties could lead industries to develop rapidly with innovative products andlor manufacturing technologies.

\section{Argument-4: Begun to implement}

The raw data of respondent argument has the majority answer (5 from 6 respondents), and can be implemented in several parts of the faculty members in the university. In addition, one's respondent answer which is not implemented yet, due to not enough budget from faculty or university in order to cover ideal activities.

On the other hand, the answer regard to the internship program, which is gender and age respondents have an influence on the answer decision to do an internship. Such as respondents who are over 50 years old have inclined to refuse to implement internship for six-month period. Responsibility as a lecturer has teaching duty. Even with gender, women resist to this policy because of personal matters, such as family and children. In addition, the previous study has resulted that male faculty members build a relationship with industries more easily than their female colleagues [30]. Those become evidence that female faculty members have resistance to cooperate activity with industries.

\subsection{Research Collaboration}

Research collaboration has meant an equal partnership between two parties (university and industry) which are represented by a researcher who is pursuing mutually interesting and beneficial research. The research is one traditional mission from universities beside teaching and service to the industry [5]. The scope of the research topic applies technologies that implement in products, machine, or organizations to increase benefit. The purpose of the interview related to research collaboration is to know ability and interest of faculty members towards work together.

The question consists of three stages, and the respondent answered three stages as well. In the question which is asked, the researcher makes a preintroduction about research collaboration on the topic. As a university lecturer has compulsory conduct research every year. Whole Indonesia universities have minimum requirements for each lecturer should conduct research and community service in society. 
Argument-5: An Enhanced researcher capability with research collaboration

The invention performance can be asses with several indicators, such as the diffusion of knowledge and the internationalization of innovative activities in universities, such as paper and patent [30]. Patents are a means of protecting original invention [5] and have legal formal in the constitution. In another word, the indicator for university performance is indicated by their number of patent and patent publication [5]. The patents and publications of university can deliver to industries need transportation, in this case facilitator has important role in the cooperation between university and industries. The facilitator's function is to influence the process in a positive manner [31] with promotion university supremacy to industries.

The raw data of the respondent argument has four answers from six responds describing that by implemented research collaboration with industry we are able to enhance research competency and have rich experiences related to industry cases. In addition, two answers describe that collaboration on research has become a problem, and the answer is such as follows:

"Become a problem, because of majority research outcomes from university un-implement, even more so the industry does not have the desire to adopt and implements. Moreover, we need a person to become communicator or relation-creator with industry, and they have a job to linked and offered university research to industry"

The problems are research outcome only form a research book report, poster, article, and journal. The mindset has to be transformed on how to research outcome had implement to industry. Based on literature research orientation comes from industrial needs, industrial problem cases and/or commercialization. The previous study explain that research collaboration includes protecting intellectual property, transferring research outcome to industries, and development of products commercial readiness [27].

In order to transfer research outcomes to industries, many researchers are incapable to handle on themselves. Furthermore, the university has need for man-power (facilitator and communicator) to become a relation-creator and have the ability to offering research outcomes to industries. The key success of university collaboration in particularly on research collaboration is to have a person that just focuses on collaboration activities.
Argument-6: Engagement researcher to develop technology of industry

The performance of the academic researchers is to be a determinant of industry engagement in collaboration. In another word, researcher quality is an important factor that influences the involvement industries to work together in collaboration with an academic researcher [32]. The research quality measured from research outcomes was implemented. The raw data of respondent argument has response which is heterogeneous, were described as follow:

Respondent-1: "this activity is implemented is good, to update technology industry knowledge. In addition, now in faculty (several faculty members) has begun into the research collaboration team with industries."

Respondent-2: "A few develops the technology from industrial standard has been begun. However, industrial recognition of technology developed academic researchers is too weak."

Respondent-3: "A research collaboration with industries has begun, however, we have barriers related to academic tasks for the faculty members. Such as teaching, community services, mentoring and administration."

Respondent-4: "Access to join in industrial technology development has resistance. Because we did not have trust from industries. In addition, the government should use the hand (interference) to solve the problem and as a bridge of communication."

Respondent-5: "The collaboration in technology development has a mission to improving quality and product for the industry, in addition to the faculty members to enhance the competencies."

Respondent-6:" We should have collaboration with industry, and the road map of collaboration has been planning as a long time ago."

Heterogeneous answers due to that research collaboration experiences of respondents are unbalanced. Nevertheless, all the respondents are accepting the research collaboration program to develop technology for industries. When they do the in-depth analysis there are two similar answers, there is an answer from respondent-2 and respondent-4. The answers explain that the university has a problem related to minimum trust and minimum recognition. Even though for starting the collaboration one should begin from the both parties' trust. [25] describe there has to exist a belief in the potential partners, feeling of trust and mutual benefit for both sides, and kind of trust can only be developed when the both put the groundwork for kind of meaningful relationship that characterizes successful partnership. 


\section{Argument-7: Begun to implement}

In addition, all the answers explain that research collaboration has begun on several faculty members. This shows minimum cooperation in the research collaboration due to a minimum of trust and recognition from industries.

\subsection{On - Job Training}

The competencies and skills every student has to improve and develop towards industrial technology. In addition, to touch technology for student in the inside of internship program, it can be obtained from on-job training program. This program is made especially for student and alumni who want to improve or implement the skill and knowledge. Onjob training could improve student or alumni. [33] describes that organization (faculty) can take advantage of on-job training, and the result is better trained, more satisfied student, as well as students who are more valuable to the organization.

In another overview, industries belief that employees who received training scored are significantly higher on job satisfaction than those who had not [33]. Industries continue developing their employees towards goal achievement as profitable enterprises. Better competency development which matches industries need to be developed in universities. The on-job training for a student with industry engagements become an important factor for both parties.

Argument- 8: Improvement student knowledge and skill cooperating with industries

Engagement industries into developing competence and skill students become the right way. [34] describes that universities should collaborate with employers and people in industries in order to provide quality competencies and skills training for students. The high quality of students' competence can influence their becoming alumni. In addition, the increasing value of student's competency influences finding the jobs more easily.

The respondent argument has the majority answer describing that engagement in industry to develop student's competency is excellent. Therefore, students as directly implement the skill and knowledge, and students get enhances up-to-date real technology. Moreover, industry has benefit to provide low cost employee from this program, such description as follow:

"The industry on-job-training be constructed to produces low-cost employee or free. In the other side, the student to obtain skill or update competence from industry technology."

The low-cost employee appears at on-job training, and then industries can continue using these students as a worker after graduate. In another overview, universities are taking benefits from technology used in training. The students get up-date real technology knowledge that the industry used. The student who has experience in the on-job training program have more value.

Argument-9: On-job training for student in industries

A significant factor in developing students' competency is university and faculty facilities. The intended facilities are a capable teacher and up-todate technologies as a mirror of industry technology. Therefore, on-job training is a good program for students and faculty members. There is a cause in the faculty that has a limitation of technology, especially university which is far from the industrial area. The major respond is as follows:

"On-job training is a good program because can improve and develop student's competencies. In addition, a student also learns from the real environment, and real technology in the industry."

The limitation of technology in faculty did not become rough ways to develop student's competency. On-job training becomes a pretty solution to these limitations. Nevertheless, one needs more effort from faculty members to cooperation with industry to goal this program.

Argument-10: Influence after internship/has experiences

On one hand, the impact of the cooperation between university and industries is an influence on interns' experience. On another hand, internship experience decreases in finding jobs and increases the probability of promotion and advancement after hiring. [35] describes that internship experience is as important regarding the person's future career choice. Based on this literature internship experience in industries has become measuring tools to indicate faculty members' capabilities.

The respondent's argument describes that faculty members especially lecturer that has rich experiences are who have rich apply his knowledge in industries collaboration. It is described as follows:

"Exactly different. The lecturer did not have experience in the industry, in the teaching process only use reference from the textbook, and did not have variation. On another side, a lecturer has teaching variation and can explain industry problems or cases."

The maximum impact of cooperation between university and industry happens when it has nifty of the facility in faculty or university to support the cooperation, which is one indicator of impact on cooperation in both, enhances knowledge and skill faculty members that has and/or internship experiences. The internship become the biggest contributor to the competency of the faculty members and appears in the teaching method in the class. 


\section{Conclusions}

The cooperation between higher education focused on university and industry is so important to university's quality, students' employment, and faculty's academic development. Several programs of university-industry cooperative approaches are suggested such as internship for faculty members, a research collaboration between academic researcher and $\mathrm{R} \& \mathrm{D}$ of enterprise, and on-job training for students.

To obtain achievement optimally, internship program should be done as long as six months period. Those can enhance the knowledge and competency of faculty members after joining the program. The faculty members in the industry implementing their knowledge and skill in real environment work and technology in solving the problem. Moreover, implement knowledge in the real environment work is to validate their academic theories, and further take the benefit from the result.

The next suggested program approach which aims to enhance cooperation between university and industries is research collaboration. The faculty members who are involved in this program should have the innovation to implement the products or manufacturing technologies. This means the major topic or research background come from industry problem and/or is based on the industry's needs. In addition, we should act to change the mind-set of research outcome not only report and journal, but also patent that can be implemented to industries.

The last suggested program approach is enhancing capability students via on-job training in the industry. The selecting industries as a place to on-job training is to deliver the real experience to a student with real environment work and technology. This becomes a benefit to the industry at recruitment time with a high capability candidate as an employee. In addition, after coming back to university, it can influence university and society.

\section{References}

[1]. Achtenhagen, C., \& Achtenhagen, L. (2019). The impact of digital technologies on vocational education and training needs An exploratory study in the German food industry. Education+ Training, 61(2), 222-233.

https://doi.org/10.1108/et-05-2018-0119

[2]. Rantala, T., \& Ukko, J. (2019). Performance evaluation to support European regional development-A university-industry perspective. European Planning Studies, 27(5), 974994.

https://doi.org/10.1080/09654313.2019.1581728
[3]. McConnell, D. P., \& Cross, S. E. (2019). Realizing the Value of Industry-University Innovation Alliances. Research-Technology Management, 62(2), 40-48. https://doi.org/10.1080/08956308.2019.1563437

[4]. Lin, J. Y. (2019). How does collaboration between universities and R\&D firms influence performance?. Management Decision. https://doi.org/10.1108/MD-07-2016-0497

[5]. Huang, C. Y. (2018). How background, motivation, and the cooperation tie of faculty members affect their university-industry collaboration outputs: an empirical study based on Taiwan higher education environment. Asia Pacific Education Review, 19(3), 413-431.

https://doi.org/10.1007/s12564-018-9546-5

[6]. Craig, T. R., \& Wikle, T. A. (2016). Perceptions and practices: Employers, educators, and students on GIS internships. Transactions in GIS, 20(6), 948-961. https://doi.org/10.1111/tgis.12201

[7]. Lakitan, B. (2013). Connecting all the dots: Identifying the "actor level" challenges in establishing effective innovation system in Indonesia. Technology in society, 35(1), 41-54. https://doi.org/10.1016/j.techsoc.2013.03.002

[8]. Fatimah, Y. A. (2017). Following Jatropha from Bandung to Sumbawa: Entanglement between University and Industry in Practice. East Asian Science, Technology and Society: an International Journal, 11(1), 35-50. https://doi.org/10.1215/18752160-3642290

[9]. Moeliodihardjo, B. Y., Soemardi, B. W., Brodjonegoro, S. S., \& Hatakenaka, S. (2012). University, industry, and government partnership: Its present and future challenges in Indonesia. ProcediaSocial and Behavioral Sciences, 52, 307-316. https://doi.org/10.1016/j.sbspro.2012.09.468

[10]. Fischer, B. B., Schaeffer, P. R., \& Vonortas, N. S. (2019). Evolution of university-industry collaboration in Brazil from a technology upgrading perspective. Technological Forecasting and Social Change, 145, 330-340. https://doi.org/10.1016/j.techfore.2018.05.001

[11]. Wen, J., \& Kobayashi, S. (2001). Exploring collaborative R\&D network:: some new evidence in Japan. Research Policy, 30(8), 1309-1319. https://doi.org/10.1016/S0048-7333(00)00152-9

[12]. Berbegal-Mirabent, J., Lafuente, E., \& Solé, F. (2013). The pursuit of knowledge transfer activities: An efficiency analysis of Spanish universities. Journal of Business Research,66(10), 2051-2059.

https://doi.org/10.1016/j.jbusres.2013.02.031

[13]. Siegel, D. S., Waldman, D., \& Link, A. (2003). Assessing the impact of organizational practices on the relative productivity of university technology transfer offices: an exploratory study. Research policy, 32(1), 27-48.

https://doi.org/https://doi.org/10.1016/S00487333(01)00196-2 
[14]. Segarra-Blasco, A., \& Arauzo-Carod, J. M. (2008). Sources of innovation and industry-university interaction: Evidence from Spanish firms. Research Policy, 37(8), 1283-1295.

https://doi.org/10.1016/j.respol.2008.05.003

[15]. Tödtling, F., Lehner, P., \& Kaufmann, A. (2009). Do different types of innovation rely on specific kinds of knowledge interactions?. Technovation, 29(1), 59-71. https://doi.org/10.1016/j.technovation.2008.05.002

[16]. Bikard, M., Vakili, K., \& Teodoridis, F. (2018). When Collaboration Bridges Institutions: The Impact of Industry Collaboration on Academic Productivity1. https://doi.org/10.2139/ssrn.2883365

[17]. Tan, P., Lin, C., \& Wang, W. (2016, March). Understanding College Students' Desire for Internships in the Information Technology Industry. In 2015 International Conference on Mechanical Science and Engineering. Atlantis Press. https://doi.org/https://doi.org/10.2991/mse-15.2016.36

[18]. Kim, H. B., \& Park, E. J. (2013). The role of social experience in undergraduates' career perceptions through internships. Journal of Hospitality, Leisure, Sport \& Tourism Education, 12(1), 70-78.

https://doi.org/10.1016/j.jhlste.2012.11.003

[19]. Coco, M. (2000). Internships: A try before you buy arrangement. SAM Advanced Management Journal, 65(2), 41.

[20]. Tijssen, R. J., Yegros-Yegros, A., \& Winnink, J. J. (2016). University-industry R\&D linkage metrics: validity and applicability in world university rankings. Scientometrics, 109(2), 677-696. https://doi.org/10.1007/s11192-016-2098-8

[21]. Subramonian, H., \& Rasiah, R. (2016). Universityindustry collaboration and technological innovation: sequential mediation of knowledge transfer and barriers in automotive and biotechnology firms in Malaysia. Asian Journal of Technology Innovation, 24(1), 77-99.

https://doi.org/10.1080/19761597.2016.1151177

[22]. Freel, M. S., \& Harrison, R. T. (2006). Innovation and cooperation in the small firm sector: Evidence from 'Northern Britain'. Regional Studies, 40(4), 289305. https://doi.org/10.1080/00343400600725095

[23]. D'este, P., \& Perkmann, M. (2011). Why do academics engage with industry? The entrepreneurial university and individual motivations. The Journal of Technology Transfer, 36(3), 316-339.

https://doi.org/10.1007/s10961-010-9153-z

[24]. Bercovitz, J., \& Feldman, M. (2006). Entpreprenerial universities and technology transfer: A conceptual framework for understanding knowledge-based economic development. The Journal of Technology Transfer, 31(1), 175-188.

https://doi.org/10.1007/s10961-005-5029-z
[25]. Azman, N., Sirat, M., Pang, V., Lai, Y. M., Govindasamy, A. R., \& Din, W. A. (2019). Promoting university-industry collaboration in Malaysia: stakeholders' perspectives on expectations and impediments. Journal of Higher Education Policy and Management, 41(1), 86-103. https://doi.org/10.1080/1360080X.2018.1538546

[26]. Mowery, D. C. (2011). Learning from one another? International policy "emulation" and universityindustry technology transfer. Industrial and Corporate Change, 20(6), 1827-1853.

https://doi.org/10.1093/icc/dtr063

[27]. Talebzadehhosseini, S., Garibay, I., KeathleyHerring, H., Al-Rawahi, Z. R. S., Garibay, O. O., \& Woodell, J. K. (2019). Strategies to enhance university economic engagement: evidence from US universities. Studies in Higher Education, 1-20. https://doi.org/10.1080/03075079.2019.1672645

[28]. Valdez, A. P., Panganiban, C. A., Lumanglas, K. R. L., Calingasan, K. A., Divino, R. S., Guico, P. J. P., ... \& Pronobe, J. M. (2012). The six-month internship training program for medical laboratory science education: an initial evaluation. JPAIR Multidisciplinary Research, 9(1). https://doi.org/10.7719/jpair.v9i1.3

[29]. Rajalo, S., \& Vadi, M. (2017). University-industry innovation collaboration:

Reconceptualization. Technovation, 62, 42-54. https://doi.org/10.1016/j.technovation.2017.04.003

[30]. Huang, C. Y. (2018). How background, motivation, and the cooperation tie of faculty members affect their university-industry collaboration outputs: an empirical study based on Taiwan higher education environment. Asia Pacific Education Review, 19(3), 413-431. https://doi.org/10.1007/s12564-018-9546-5

[31]. Zaharia, N., \& Kaburakis, A. (2016). Bridging the gap: US sport managers on barriers to industryacademia research collaboration. Journal of Sport Management, 30(3), 248-264.

https://doi.org/10.1123/jsm.2015-0010

[32]. Perkmann, M., King, Z., \& Pavelin, S. (2011). Engaging excellence? Effects of faculty quality on university engagement with industry. Research Policy, 40(4), 539-552.

https://doi.org/10.1016/j.respol.2011.01.007

[33]. Schmidt, S. W. (2004). The relationship between satisfaction with on-the-job training and overall job satisfaction. Midwest Research-to-Practice Conference in Adult, Continuing, and Community Education. http://hdl.handle.net/1805/276

[34]. Tran, L. H. N. (2018). Game of blames: Higher education stakeholders' perceptions of causes of Vietnamese graduates' skills gap. International Journal of Educational Development, 62(C), 302-312. https://doi.org/10.1016/j.ijedudev.2018.07.005

[35]. Bukaliya, R. (2012). The Potential Benefits and Challenges of Internship Programmes in an ODL Institution: a Case for the Zimbabwe Open University. International Journal on New Trends in Education and Their Implications, 3(1), 118-133. 